\title{
(3) Water Oxidation Electrocatalysis with a Cobalt-Borate-Based Hybrid System under Neutral Conditions
}

\author{
Emine A. Turhan, ${ }^{[a]}$ Satya Vijaya Kumar Nune, ${ }^{[a, b]}$ Emine Ülker, ${ }^{*[c]}$ Ufuk Şahin, ${ }^{[d]}$ \\ Yavuz Dede, ${ }^{*[\mathrm{~d}]}$ and Ferdi Karadas ${ }^{*[a, e]}$
}

\begin{abstract}
The development of new water oxidation electrocatalysts that are both stable and efficient, particularly in neutral conditions, holds great promise for overall water splitting. In this study, the electrocatalytic water oxidation performance of a new cobalt-based catalyst, $\mathrm{CO}_{3}\left(\mathrm{BO}_{3}\right)_{2}$, with a Kotoite-type crystal structure is investigated under neutral conditions. The catalyst is also hybridized with CNTs to enhance its electrocatalytic properties. A remarkable increase in catalytic current along with a significant shift in the onset overpotential is observed in $\mathrm{Co}_{3}\left(\mathrm{BO}_{3}\right)_{2} @ \mathrm{CNT}$. Additionally, CNT addition also greatly influences the surface concentra-
\end{abstract}

tion of the catalyst: $12.7 \mathrm{nmol} \mathrm{cm}{ }^{-2}$ for $\mathrm{Co}_{3}\left(\mathrm{BO}_{3}\right)_{2} @ \mathrm{CNT}$ compared with $3.9 \mathrm{nmolcm}^{-2}$ for $\mathrm{CO}_{3}\left(\mathrm{BO}_{3}\right)_{2}$. $\mathrm{Co}_{3}\left(\mathrm{BO}_{3}\right)_{2} @ \mathrm{CNT}$ demands overpotentials of 303 and $487 \mathrm{mV}$ to attain current densities of 1 and $10 \mathrm{~mA} \mathrm{~cm}^{-2}$, respectively, at $\mathrm{pH}$ 7. Electrochemical and characterization studies performed over varying $\mathrm{pH}$ conditions reveal that the catalyst retains its stability over a pH range of 3-14. Multi-reference quantum chemical calculations are performed to study the nature of the active cobalt sites and the effect of boron atoms on the activity of the cobalt ions.

\section{Introduction}

Significant efforts have been devoted recently to the development of water oxidation electrocatalysts that operate with high efficiency and stability at low overpotentials. ${ }^{[1,2]}$ Even though $\mathrm{IrO}_{2}$ and $\mathrm{RuO}_{2}$ are considered as efficient and highly active catalysts for the oxygen evolution reaction (OER), their scarcity and instability in alkaline media hinder their practical utility. ${ }^{[3]}$ There is therefore a need for the discovery of catalysts incorporating earth-abundant materials with activities rivalling those of noble-metal catalysts.

[a] E. A. Turhan, Dr. S. V. K. Nune, Prof. Dr. F. Karadas Department of Chemistry, Bilkent University 06800 Ankara (Turkey)

E-mail:karadas@fen.bilkent.edu.tr

[b] Dr. S. V. K. Nune

Centre of Excellence (COEXAMMPC), Department of Science and Humanities Vignan's Foundation for Science, Technology, and Research (VFSTR) University, Vadlamudi 522213, Andhra Pradesh (India)

[c] Prof. E. Ülker

Department of Chemistry, Faculty of Arts \& Sciences

Recep Tayyip Erdogan University, 53100 Rize (Turkey) E-mail:emine.kapancik@erdogan.edu.tr

[d] U. Şahin, Prof. Y. Dede

Faculty of Science, Department of Chemistry, Gazi University

Ankara 06500 (Turkey)

E-mail:dede@gazi.edu.tr

[e] Prof. Dr. F. Karadas

UNAM-Institute of Materials Science and Nanotechnology Bilkent University 06800 Ankara (Turkey)

$\square$ Supporting information and the ORCID identification number(s) for the au-

(iD) thor(s) of this article can be found under:

https://doi.org/10.1002/chem.201801412.
Recently, Co-Pi films, electrodeposited from Coll solution in the presence of a phosphate buffer, have emerged as a new class of electrocatalysts for water oxidation. ${ }^{[4]}$ Cobalt-based water oxidation electrocatalysts have been the center of focus since then. ${ }^{\left[{ }^{-11]}\right.}$ In general, two methods have been employed to introduce new cobalt-based electrocatalysts: 1) the addition of other metal ions to cobalt oxides, or so-called doping; and 2) the use of different anions to prepare cobalt-based inorganic frameworks. The former method has been employed successfully to prepare mixed-metal oxides with enhanced catalytic activities. For example, the studies performed on $\mathrm{NiCO}_{2} \mathrm{O}_{4}{ }^{[12]}$ $\mathrm{Zn}_{x} \mathrm{Co}_{3-x} \mathrm{O}_{4}{ }^{[13]} \mathrm{CoAl}_{2} \mathrm{O}_{4}{ }^{[14]} \mathrm{Cu}_{x} \mathrm{Co}_{y} \mathrm{O}_{4}{ }^{[15]}$ and $\mathrm{Co}_{2.25} \mathrm{Cr}_{0.75} \mathrm{O}_{4}{ }^{[16]}$ led to the conclusion that incorporation of different $3 \mathrm{~d}$ metal ions to cobalt oxides is a simple and efficient way to enhance the OER activity in comparison to $\mathrm{CO}_{3} \mathrm{O}_{4}$. The latter method suggests the use of anionic groups other than the oxide group, for example, boride, ${ }^{[17]}$ nitride, ${ }^{[18]}$ phosphide, ${ }^{[19,20]}$ cyanide, ${ }^{[21,22]}$ and phosphate. ${ }^{[23]}$ Of these, cobalt phosphates have been studied intensely owing to their diversity, facile synthesis, and more specifically, the crucial role of the phosphate group in the water oxidation activity and robustness of Co-Pi catalysts. Some promising examples of metal phosphates studied in this field include $\mathrm{Na}_{2} \mathrm{CoP}_{2} \mathrm{O}_{7}, \mathrm{NaCoPO}_{4}, \mathrm{Li}_{2} \mathrm{CoP}_{2} \mathrm{O}_{7}, \mathrm{LiCoPO}_{4}$, and $\mathrm{CO}_{3}\left(\mathrm{PO}_{4}\right)_{2} \cdot{ }^{[23,24]} \mathrm{Kim}$ et al. claimed that the enhanced catalytic activity of phosphates is a result of the structural flexibility of the phosphate group.

Recently, the use of borate anions to construct robust and electroactive cobalt-based structures has been revisited. The history of Co-Bi catalysts in the field of water oxidation can be divided into two eras according to the role of the borate group in the structure. In the first era, Co-Bi catalysts were pre- 
pared by electrodeposition of cobalt ions in a borate buffer. Although the structure is not clear owing to the amorphous nature of the catalysts, the borate groups are considered to be only counter anions, playing a role in the formation and stabilization of layered cobalt oxides. The first study that engages the borate anion with the field of water oxidation is the investigation of $\mathrm{Co}-\mathrm{Bi}$ electrodes, which were prepared through electrodeposition of a Co" salt in a borate buffer. ${ }^{[25]} \mathrm{X}$-ray diffraction studies together with atomic pair distribution function (PDF) analysis of powder samples revealed that these electrodes possess dimensionally reduced mesostructures, which resemble the structure of layered cobaltates such as $\mathrm{LiCoO}_{2}$. Although there have been other efforts to prepare metal borate electrodes, they led to the preparation of metal oxides rather than metal borates, which shows that the borate group mainly plays a role in controlling the dimensionality and morphology of the system. ${ }^{[26,27]}$ First-generation Co-Bi catalysts took a back seat in the field mainly because of their relatively lower catalytic activities compared with well-known Co-Pi systems. In the second era, novel synthetic methods were used to prepare second-generation $\mathrm{Co}-\mathrm{Bi}$ catalysts, in which the borate groups are directly coordinated to cobalt ions. Such catalysts have proven to be efficient and robust catalysts, especially when hybridized with carbon-based supports such as graphene and carbon cloth. These novel methods include 1) the use of $\mathrm{BH}_{4}^{-}$ reducing agent as the boron source, ${ }^{[28]}$ and 2) electrochemical surface tuning of cobalt-based films such as $\mathrm{CoS}_{2}, \mathrm{CoSe}_{2}$ $\mathrm{CoFe}_{2} \mathrm{O}_{4}$, CoP, Fe-doped $\mathrm{Co}_{3} \mathrm{O}_{4}$, and electrodeposited a-Co(OH) in a borate buffer. ${ }^{[29-34]}$ Cobalt borate nanosheets deposited on graphene obtained with the former method exhibit an exceptional onset overpotential of $235 \mathrm{mV}$ and a current density of $14.4 \mathrm{~mA} \mathrm{~cm}^{-2}$ at $1.8 \mathrm{~V}$, whereas an overpotential of only $420 \mathrm{mV}$ is required to reach a current density of $10 \mathrm{mAcm}^{-2}$ with Co-Bi obtained with the latter method. Sun et al. reported that the catalytic activity could be improved further by partial substitution of cobalt atoms with nickel ions in cobalt-borate nanowire arrays to achieve a lower overpotential (388 $\mathrm{mV}$ for $10 \mathrm{~mA} \mathrm{~cm}^{-2}$ at pH 9.2). ${ }^{[35]}$ Furthermore, a bimetallic NiCo-Bi catalyst, which was directly converted from NiCo-layered double hydroxide on nickel foam through oxidative polarization in borate electrolyte, performs at an overpotential of $430 \mathrm{mV}$ for a current density of $10 \mathrm{mAcm}^{-2}$. ${ }^{[36]}$ These studies reveal that cobalt borate systems as electrocatalysts could be a promising direction in the field of water oxidation.

Despite the promising electrocatalytic performance obtained with previously reported cobalt borate systems, no clear description of the structure was reported owing to the amorphous nature of the catalysts, which prevents solid attempts at establishing a structure-property correlation. The primary goal of previous studies on cobalt borate systems has been to enhance the electrocatalytic activity of cobalt-based systems. This was achieved successfully by preparing hybrid systems directly through in situ preparation techniques, which led to the formation of amorphous cobalt borate structures. Given the promising electrocatalytic activity and robustness of cobalt borate hybrid systems, this study, on the other hand, aims to 1) establish a structure-property correlation using both experi- mental and computational methods, and 2) investigate the effect of the carbon support on both the morphology and the structure of cobalt borate. Therefore, a cobalt borate with a well-known Kotoite-type crystal structure, $\mathrm{CO}_{3}\left(\mathrm{BO}_{3}\right)_{2}$, and its hybrid with multiwalled carbon nanotubes (CNTs), $\mathrm{Co}_{3}\left(\mathrm{BO}_{3}\right)_{2} @ \mathrm{CNT}$, are reported. Electrochemical studies were performed with $\mathrm{CO}_{3}\left(\mathrm{BO}_{3}\right)_{2}$ mainly to investigate its $\mathrm{pH}$-dependent stability and to obtain experimental evidence about the nature of the rate-determining step. $\mathrm{CO}_{3}\left(\mathrm{BO}_{3}\right)_{2} @ \mathrm{CNT}$ was used to investigate the effect of CNTs on the morphology, surface concentration, and hence, electrocatalytic performance of cobalt borate systems under neutral conditions. Computational studies were performed to investigate the factors affecting the critical $\mathrm{O}-\mathrm{O}$ bond formation step and to understand the influence of electron-deficient boron atoms on the catalytic activity of cobalt sites.

\section{Results and Discussion}

Cobalt borate was synthesized simply through a two-step solid-state reaction. The XRD pattern (Figure S1, Supporting Information) corresponds well with Kotoite $\left[\mathrm{Mg}_{3}\left(\mathrm{BO}_{3}\right)_{2}\right]$, as intended, confirming the molecular formula of the derivative as $\mathrm{Co}_{3}\left(\mathrm{BO}_{3}\right)_{2}$. The crystal structure belongs to the Pnnm (58) space group with an orthorhombic unit cell, and can be described simply as a 3D framework consisting of octahedral cobalt sites connected with oxide atoms that belong to triangular $\mathrm{BO}_{3}$ groups (Figure $1 \mathrm{a}$ ). Each cobalt center adopts a slightly distorted octahedral geometry, surrounded by four borate groups (Figure $1 \mathrm{~b}$ ). Each borate group contains three oxygen atoms, two of which are shared by three Coll sites, with the remaining

a)

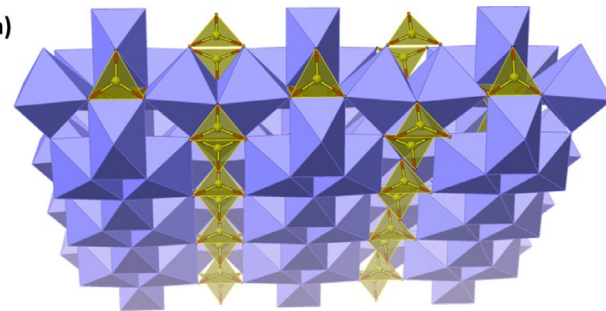

b)
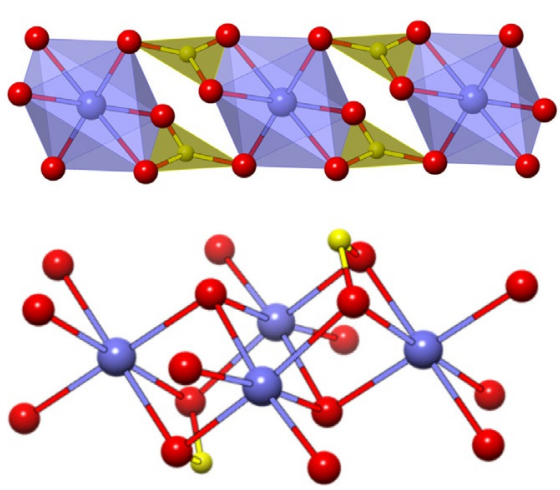

Figure 1. a) Crystal structure of $\mathrm{CO}_{3}\left(\mathrm{BO}_{3}\right)_{2}$ (purple octahedrons and yellow triangles represent $\left[\mathrm{CoO}_{6}\right]$ and $\left[\mathrm{BO}_{3}\right]$ groups. $\mathrm{Co}, \mathrm{B}$, and $\mathrm{O}$ atoms represented by purple, yellow, and red colors, respectively. b) $2 \mathrm{D}$ packing diagram of crystal structure showing arrangement of octahedrons with respect to one another. c) Molecular structure displaying $\left[\mathrm{CoBO}_{4}\right]$ cubane units. 
one connected to only two Co" sites. A closer inspection of the crystal structure shows that it is composed of $\mathrm{CO}_{3} \mathrm{BO}_{4}$-type cubane units that resemble the $\mathrm{Mn}_{3} \mathrm{CaO}_{4}$ cubane units (one active metal center is replaced with an electron-deficient atom) that operate in photosystem II (Figure $1 \mathrm{C}$ ). ${ }^{[3]}$

SEM analysis of $\mathrm{CO}_{3}\left(\mathrm{BO}_{3}\right)_{2}$ (Figure $2 \mathrm{a}$ ) reveals a uniformly distributed, densely packed catalyst with a high degree of agglomeration. In the case of $\mathrm{CO}_{3}\left(\mathrm{BO}_{3}\right)_{2} @ \mathrm{CNT}$, however, as shown in Figure $2 \mathrm{~b}$, a well-defined tubular geometry was observed,

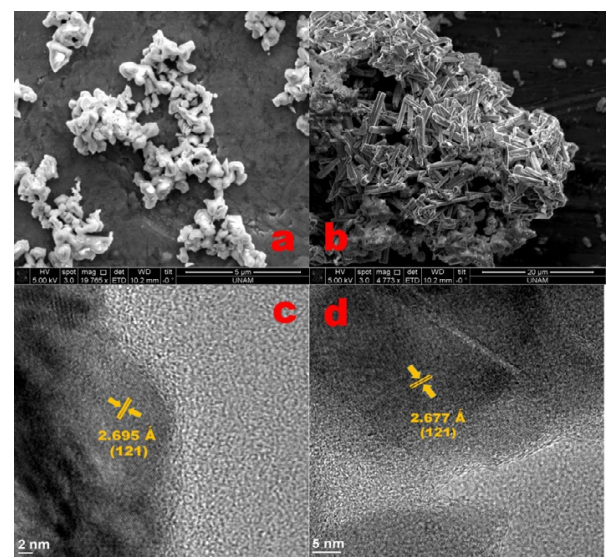

Figure 2. a) SEM image of $\mathrm{Co}_{3}\left(\mathrm{BO}_{3}\right)_{2}$; b) SEM image of $\mathrm{Co}_{3}\left(\mathrm{BO}_{3}\right)_{2} @ \mathrm{CNT}$; c) HRTEM image of $\mathrm{CO}_{3}\left(\mathrm{BO}_{3}\right)_{2}$; and d) HRTEM image of $\mathrm{CO}_{3}\left(\mathrm{BO}_{3}\right)_{2} @ \mathrm{CNT}$.

which can be attributed to CNTs acting as supports for the catalyst. This change in the geometry can also be seen with the slight change in the d-spacing of the (121) phase from highresolution TEM (HRTEM) images (Figure $2 c, d$ ). This change was also confirmed by XRD results, in which the diffraction angle $(2 \theta)$ of the (121) plane for $\mathrm{CO}_{3}\left(\mathrm{BO}_{3}\right)_{2} @ \mathrm{CNT}$ shifts slightly to higher angles compared with $\mathrm{CO}_{3}\left(\mathrm{BO}_{3}\right)_{2}$ as a result of the decrease in interplanary distance between (121) planes. The comparison of XRD patterns (Figure S1) also reveals that cobalt borate in $\mathrm{Co}_{3}\left(\mathrm{BO}_{3}\right)_{2} @ \mathrm{CNT}$ is crystalline and has the same crystalline structure as $\mathrm{Co}_{3}\left(\mathrm{BO}_{3}\right)_{2}$.

Figure 3 shows the results of XPS analysis of $\mathrm{CO}_{3}\left(\mathrm{BO}_{3}\right)_{2}$ and $\mathrm{CO}_{3}\left(\mathrm{BO}_{3}\right)_{2} @ \mathrm{CNT}$ samples. Both the samples exhibit a broad Co $2 p_{3 / 2}$ signal at around $781 \mathrm{eV}$ and $\mathrm{Co} 2 \mathrm{p}_{1 / 2}$ signal at around $796 \mathrm{eV}$, respectively (Figure $3 \mathrm{a}$ ). Additionally, broad and distinguishable satellite signals are also observed at around 786 and $803 \mathrm{eV}$, respectively, which correspond with $\mathrm{Co}^{2+} \cdot{ }^{[38]} \mathrm{B} 1 \mathrm{~s}$ (Figure $3 \mathrm{~b}$ ) and $\mathrm{O} 1 \mathrm{~s}$ (Figure $3 \mathrm{c}$ ) signals are observed at approximately 192 and $533 \mathrm{eV}$, respectively, for $\mathrm{CO}_{3}\left(\mathrm{BO}_{3}\right)_{2}$. A mild shift toward slightly higher binding energies is observed in $\mathrm{CO}_{3}\left(\mathrm{BO}_{3}\right)_{2} @ \mathrm{CNT}$, which can be attributed to the influence of the electron densities of the carbon atoms from the CNTs to $\mathrm{Co}_{3}\left(\mathrm{BO}_{3}\right)_{2}$.

The catalytic activity of $\mathrm{CO}_{3}\left(\mathrm{BO}_{3}\right)_{2}$ coated on FTO toward water oxidation was evaluated by cyclic voltammetry (CV) at a scan rate of $50 \mathrm{mV} \mathrm{s}^{-1}$ in KPi buffer solution $(\mathrm{pH} 7)$ with $1 \mathrm{M}$ $\mathrm{KNO}_{3}$ as electrolyte in the range $0.2-1.7 \mathrm{~V}$ versus NHE (Figure $4 \mathrm{a}$ ). The $\mathrm{CV}$ of $\mathrm{CO}_{3}\left(\mathrm{BO}_{3}\right)_{2}$ displays a quasireversible redox couple with an oxidation peak at around $1.10 \mathrm{~V}$ and a reduc- a)

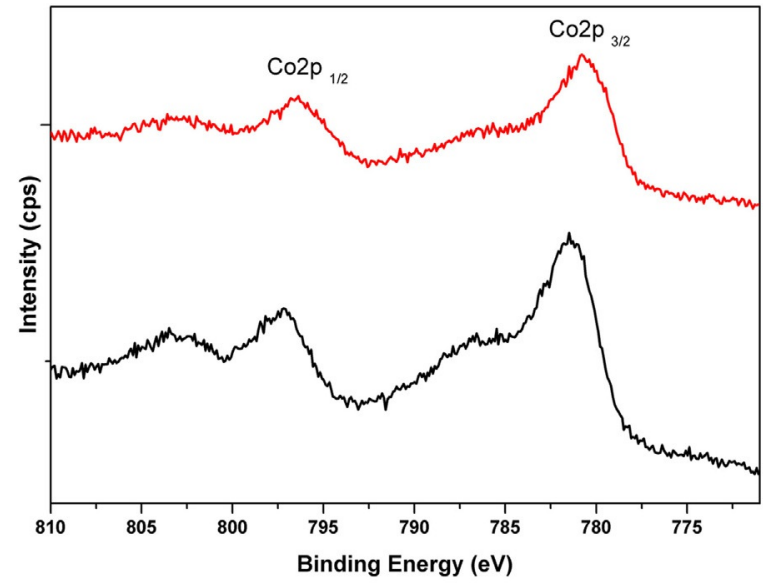

b)
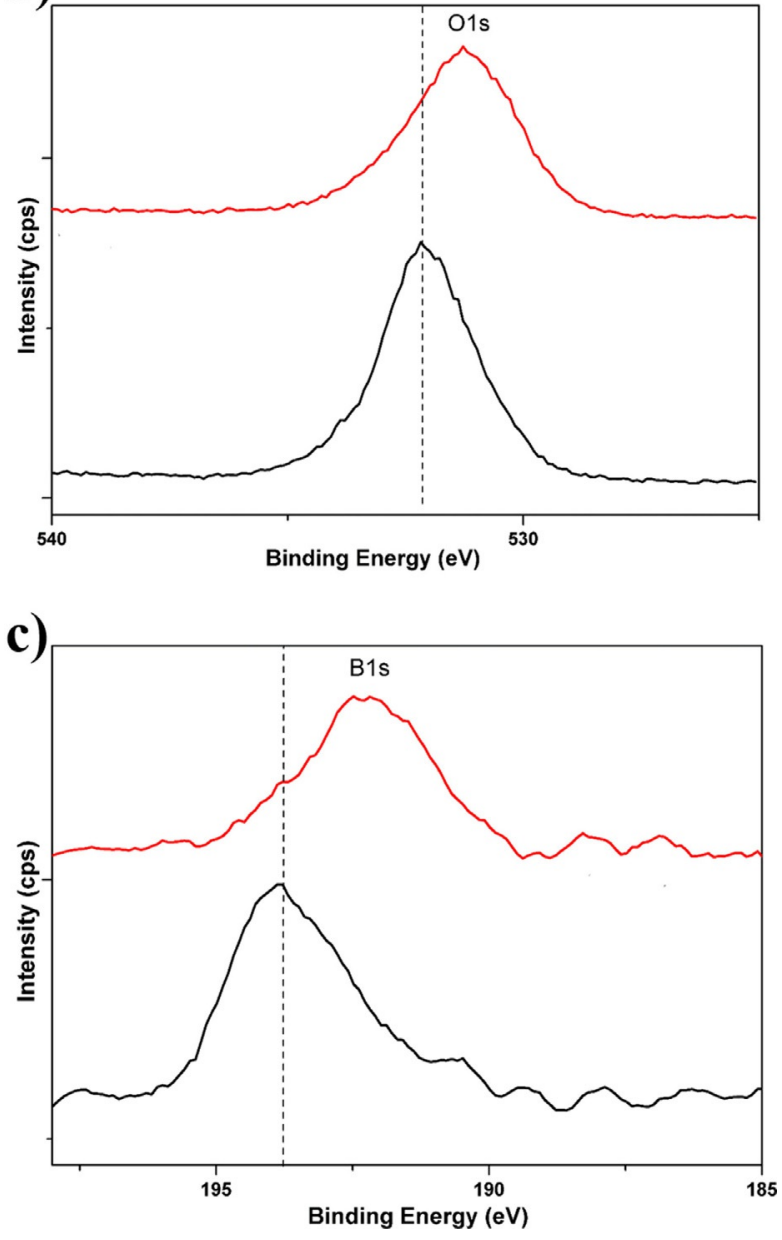

Figure 3. XPS profiles of a) $\mathrm{Co} 2 \mathrm{p}$, b) O 1s, and c) B 1s signals for $\mathrm{CO}_{3}\left(\mathrm{BO}_{3}\right)_{2}$ (top, red signals) and $\mathrm{CO}_{3}\left(\mathrm{BO}_{3}\right)_{2} @ \mathrm{CNT}$ (bottom, black signals).

tion peak at $1.00 \mathrm{~V}$ versus the NHE reference electrode $\left(E_{1 / 2}=\right.$ $1.05 \mathrm{~V}, E_{\mathrm{c}}-E_{\mathrm{a}}=100 \mathrm{mV}$ ), which can be assigned to the $\mathrm{Co}^{2+}$ $/ \mathrm{Co}^{3+}$ redox couple. An anodic peak was also observed at around $1.50 \mathrm{~V}$, which can be assigned to the formation a $\mathrm{Co}^{\mathrm{IV}}$ intermediate species. ${ }^{[39,40]}$ A similar profile was observed for $\mathrm{Co}_{3}\left(\mathrm{BO}_{3}\right)_{2} @ \mathrm{CNT}$. The comparison of CVs of $\mathrm{Co}_{3}\left(\mathrm{BO}_{3}\right)_{2} @ \mathrm{CNT}$, 
a)

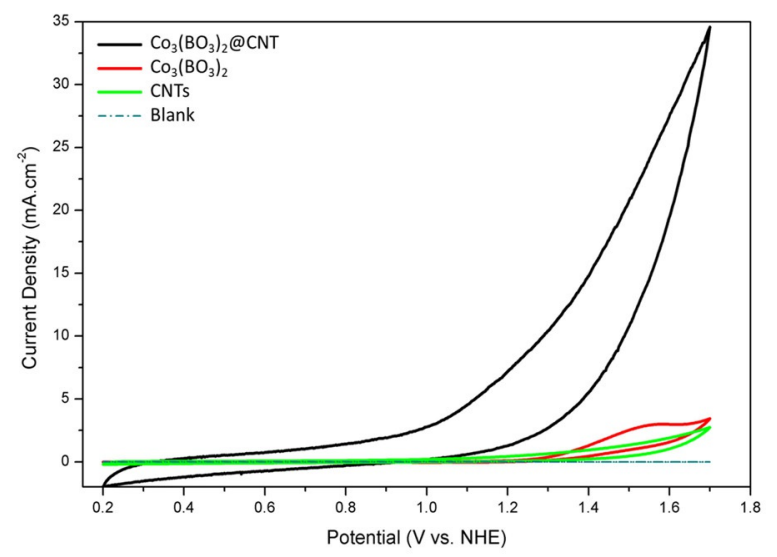

b)

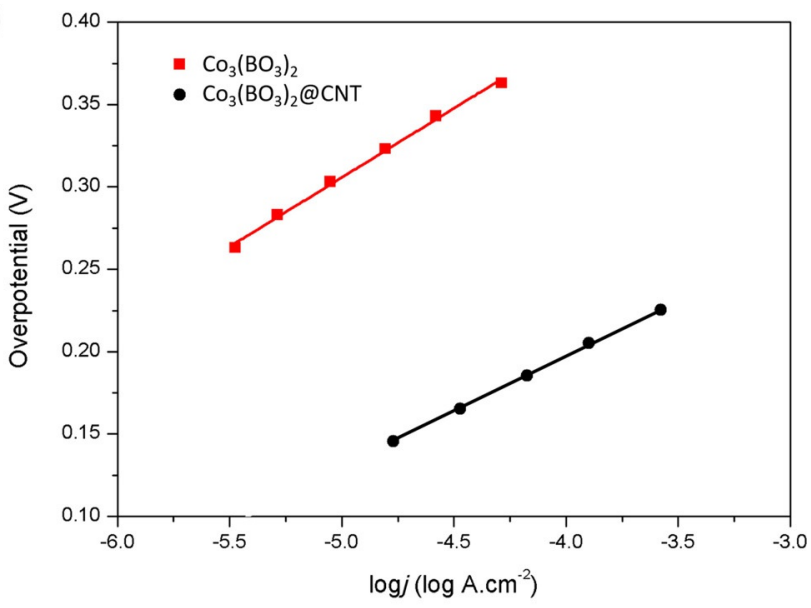

c)

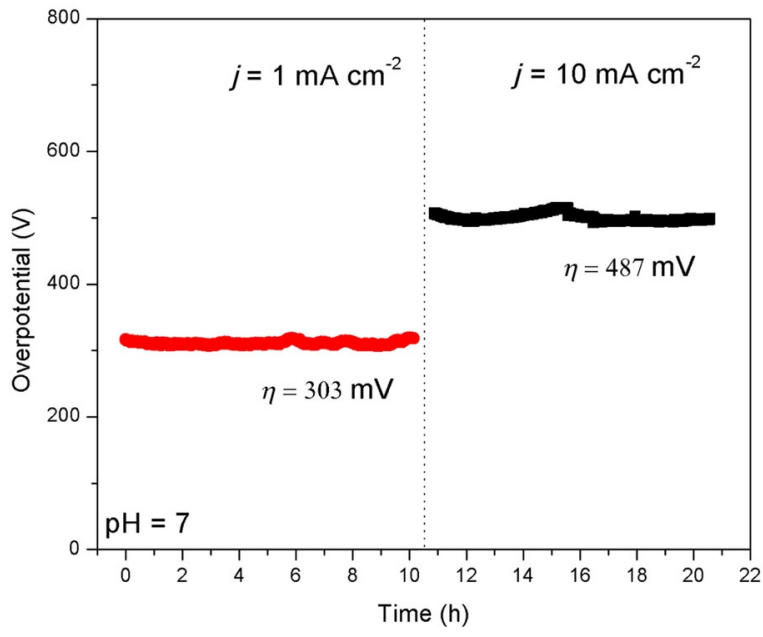

Figure 4. a) Cyclic voltammogram of $\mathrm{Co}_{3}\left(\mathrm{BO}_{3}\right)_{2} @ \mathrm{CNT}$ (black line), $\mathrm{CO}_{3}\left(\mathrm{BO}_{3}\right)_{2}$ (red line), and activated CNTs (green line) -modified FTO electrode recorded in $50 \mathrm{~mm} \mathrm{KPi}$ buffer solution with $1 \mathrm{M} \mathrm{KNO}_{3}$ as electrolyte at $\mathrm{pH} 7.0$ with a $50 \mathrm{mV} \mathrm{s}^{-1}$ scan rate. Blank scan recorded under same conditions without the catalyst (dashed line). b) Tafel linearity obtained for $\mathrm{Co}_{3}\left(\mathrm{BO}_{3}\right)_{2} @ \mathrm{CNT}$ (bottom, black) and $\mathrm{CO}_{3}\left(\mathrm{BO}_{3}\right)_{2}$ (top, red) -modified electrodes. Measurements were

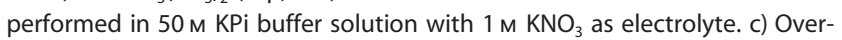
potential versus time data of $\mathrm{CO}_{3}\left(\mathrm{BO}_{3}\right)_{2} @ \mathrm{CNT}$ under a constant current density of $1 \mathrm{~mA} \mathrm{~cm}^{-2}$ (red line) and $10 \mathrm{~mA} \mathrm{~cm}^{-2}$ (black line) in $\mathrm{pH} 7$ phosphate buffer.

$\mathrm{CO}_{3}\left(\mathrm{BO}_{3}\right)_{2}$, and CNTs clearly indicates a remarkable increase in the catalytic current as well as a significant shift of the onset overpotential to less positive potentials upon the addition CNTs to $\mathrm{CO}_{3}\left(\mathrm{BO}_{3}\right)_{2}$ (Figure $4 \mathrm{a}$ ).

Analysis of Tafel plots shows that the slope $\left(67 \mathrm{mV} \mathrm{dec}^{-1}\right)$ for $\mathrm{CO}_{3}\left(\mathrm{BO}_{3}\right)_{2} @ \mathrm{CNT}$ is slightly lower than that obtained for $\mathrm{CO}_{3}\left(\mathrm{BO}_{3}\right)_{2}\left(84 \mathrm{mV} \mathrm{dec}^{-1}\right)$, mainly owing to the conductive behavior of CNTs (Figure $4 \mathrm{~b}$ ). An improvement in the onset overpotential was also observed with $\mathrm{CO}_{3}\left(\mathrm{BO}_{3}\right)_{2} @ \mathrm{CNT}$ compared with $\mathrm{CO}_{3}\left(\mathrm{BO}_{3}\right)_{2}$. An onset overpotential of $206 \mathrm{mV}$ is recorded, which is one of the lowest overpotentials achieved among cobalt-based catalyst films including CoPi $(\eta: 280 \mathrm{mV}){ }_{1}{ }^{[4]}$ $\mathrm{Co}\left(\mathrm{PO}_{3}\right)_{2}(\eta: 310 \mathrm{mV}){ }_{1}^{[41]} \mathrm{CoNCN}(\eta: 320 \mathrm{mV}){ }_{1}^{[42]} \mathrm{CoFe}(\mathrm{CN})_{5}-\mathrm{PVP}$ $(\eta: 360 \mathrm{mV}),{ }^{[38]} \mathrm{Co}_{3} \mathrm{O}_{4}(\eta: 434 \mathrm{mV}),{ }^{[43]}$ and Co-Bi NS/G $(\eta$ : $235 \mathrm{mV}$ ). ${ }^{[28]}$ For $\mathrm{CO}_{3}\left(\mathrm{BO}_{3}\right)_{2}$, an overpotential (lower limit) of $474 \mathrm{mV}$ for a current density of $1 \mathrm{mAcm}^{-2}$ is extracted from the Tafel plot, which is similar to that for CoNCN/FTO, ${ }^{[42]}$ much lower than that required for cobalt hexacyanoferrates on the FTO electrode $(\eta>600 \mathrm{mV})^{[21]}$ and higher than typical oxides such as Co-Bi/FTO ${ }^{[27]}$ and Co-Pi/ITO. ${ }^{[26]}$ Tafel analysis yields overpotentials of 264 and $331 \mathrm{mV}$ for current densities of 1 and $10 \mathrm{~mA} \mathrm{~cm}^{-2}$ for $\mathrm{Co}_{3}\left(\mathrm{BO}_{3}\right)_{2} @ \mathrm{CNT}$ at pH 7.

Chronopotentiometric studies at these current densities, each of which has a $10 \mathrm{~h}$ duration, have also been performed for $\mathrm{Co}_{3}\left(\mathrm{BO}_{3}\right)_{2} @ \mathrm{CNT}$ under neutral conditions to evaluate their long-term activities and stabilities (Figure $4 \mathrm{c}$ ). At $1 \mathrm{mAcm}^{-2}$, it maintains a stable current density of $303 \mathrm{mV}$. This value was consistent with the one extracted from the Tafel plot $(264 \mathrm{mV})$. At a current density of $10 \mathrm{~mA} \mathrm{~cm}^{-2}$, the overpotential remained stable at $487 \mathrm{mV}$, which is one of the lowest overpotentials obtained among cobalt-based electrocatalysts deposited on FTO under neutral conditions. The overpotential obtained is also very close to those obtained for Co-Bi NS/G $(\approx 490 \mathrm{mV})$, Co$\mathrm{Fe}_{2} \mathrm{O}_{4} @ \mathrm{Co}-\mathrm{FeBi} / \mathrm{CC}(460 \mathrm{mV}), \mathrm{NiCo}-\mathrm{Bi} / \mathrm{NF}(430 \mathrm{mV})$, and higher than that obtained for Co-Bi NA/Ti $(420 \mathrm{mV}$ ) [in borate electrolyte, $(\mathrm{pH}$ 9.2)]. It is notable that $\mathrm{pH} 7$ was used in the present work. A list of electrocatalytic performances of all cobalt borate catalysts reported in the literature is given in Table S1 (Supporting Information).

The effect of CNTs on the morphology of the catalyst can also be observed from the change in surface concentration, which was extracted from the slope of peak current density and scan rate plot (Figure S2, Supporting Information). The surface concentration of $\mathrm{Co}_{3}\left(\mathrm{BO}_{3}\right)_{2}$ was calculated as $3.9 \mathrm{nmol} \mathrm{cm}^{-2}$, whereas the value is $12.7 \mathrm{nmol} \mathrm{cm}^{-2}$ for $\mathrm{Co}_{3}\left(\mathrm{BO}_{3}\right)_{2} @ \mathrm{CNT}$. Turnover frequencies (TOFs) of catalysts, extracted from Tafel plots and the aforementioned surface concentration data, were estimated as $7.3 \times 10^{-2} \mathrm{~s}^{-1}$ and $2.3 \times$ $10^{-1} \mathrm{~s}^{-1}$ at $400 \mathrm{mV}$ for $\mathrm{Co}_{3}\left(\mathrm{BO}_{3}\right)_{2}$ and $\mathrm{Co}_{3}\left(\mathrm{BO}_{3}\right)_{2} @ \mathrm{CNT}$, respectively (Figure $\mathrm{S} 3$, Supporting Information). At the same overpotential, Co-Bi, Co-Bi NA/Ti, Ni-Co-Bi/CC, Co-Bi NA/CC, Co$\mathrm{Fe}_{2} \mathrm{O}_{4} @ \mathrm{Co}-\mathrm{FeBi} / \mathrm{CC}$, and $\mathrm{Fe}-\mathrm{CO}_{3} \mathrm{O}_{4} @ \mathrm{Fe}-\mathrm{Co}-\mathrm{Bi} / \mathrm{CC}$ films exhibit TOFs of $\approx 1.5 \times 10^{-3} \mathrm{~s}^{-1}, 1.04 \times 10^{-1} \mathrm{~s}^{-1}, \approx 1.2 \times 10^{-1} \mathrm{~s}^{-1}, 3.53 \times$ $10^{-2 \mathrm{~s}-1}, 6.8 \times 10^{-2} \mathrm{~s}^{-1}$, and $1.4 \times 10^{-1} \mathrm{~s}^{-1}$, respectively. ${ }^{[26,29-31,33,35]}$ It is also notable that $\mathrm{Ni}-\mathrm{Co}-\mathrm{Bi} / \mathrm{CC}$ and $\mathrm{CO}_{3}\left(\mathrm{BO}_{3}\right)_{2} @ \mathrm{CNT}$ have similar surface concentrations $\left(\approx 12.3 \mathrm{nmol} \mathrm{cm}^{-2}\right.$ and $12.7 \mathrm{nmol} \mathrm{cm}^{-2}$ ) extracted from the linear relationship between peak current and scan rate during CV tests, and they exhibit TOFs of around $1.2 \times 10^{-1} \mathrm{~s}^{-1}$ and $2.3 \times 10^{-1} \mathrm{~s}^{-1}$, respectively. A 
TOF value of $2 \times 10^{-3} \mathrm{~s}^{-1}$ was reported for a cobalt oxide film and CoFe PBA at $\mathrm{pH} 7, \eta=410 \mathrm{mV}$, and $305 \mathrm{mV}$, respectively. The same TOF can be achieved at much lower overpotentials with the present catalysts, $\mathrm{CO}_{3}\left(\mathrm{BO}_{3}\right)_{2} \quad(262 \mathrm{mV})$ and $\mathrm{Co}_{3}\left(\mathrm{BO}_{3}\right)_{2} @ \mathrm{CNT}(212 \mathrm{mV})$.

Figure $5 \mathrm{a}$ shows charge accumulated over time in a controlled-potential electrolysis at $1.4 \mathrm{~V}$ (vs. NHE) for $\mathrm{Co}_{3}\left(\mathrm{BO}_{3}\right)_{2} @ \mathrm{CNT}, \mathrm{CO}_{3}\left(\mathrm{BO}_{3}\right)_{2}$, and blank FTO at pH 7.0. The total charge accumulated during electrolysis was obtained as $5.5 \mathrm{C}$ for the $\mathrm{CO}_{3}\left(\mathrm{BO}_{3}\right)_{2} @ \mathrm{CNT}$ catalyst, which is approximately 5.5 times higher than that for $\mathrm{Co}_{3}\left(\mathrm{BO}_{3}\right)_{2}(1 \mathrm{C})$. In contrast, negligible charge was passed upon using a blank FTO electrode as the working electrode under the same conditions. The Faradaic efficiency for the $\mathrm{CO}_{3}\left(\mathrm{BO}_{3}\right)_{2} @ \mathrm{CNT}$ catalyst was measured with an oxygen probe inserted into a gas-tight anodic compartment during electrolysis. The charge passed over electrolysis was used to determine the theoretical oxygen yield (Figure $5 \mathrm{~b}$ ). The close match between the number of dissolved oxygen molecules detected during bulk electrolysis and the theoretical amount of evolved oxygen assuming a Faradaic efficiency of $100 \%$ indicates that any side reactions can be ruled out, and hence, the only origin of catalytic current is the oxygen evolu-
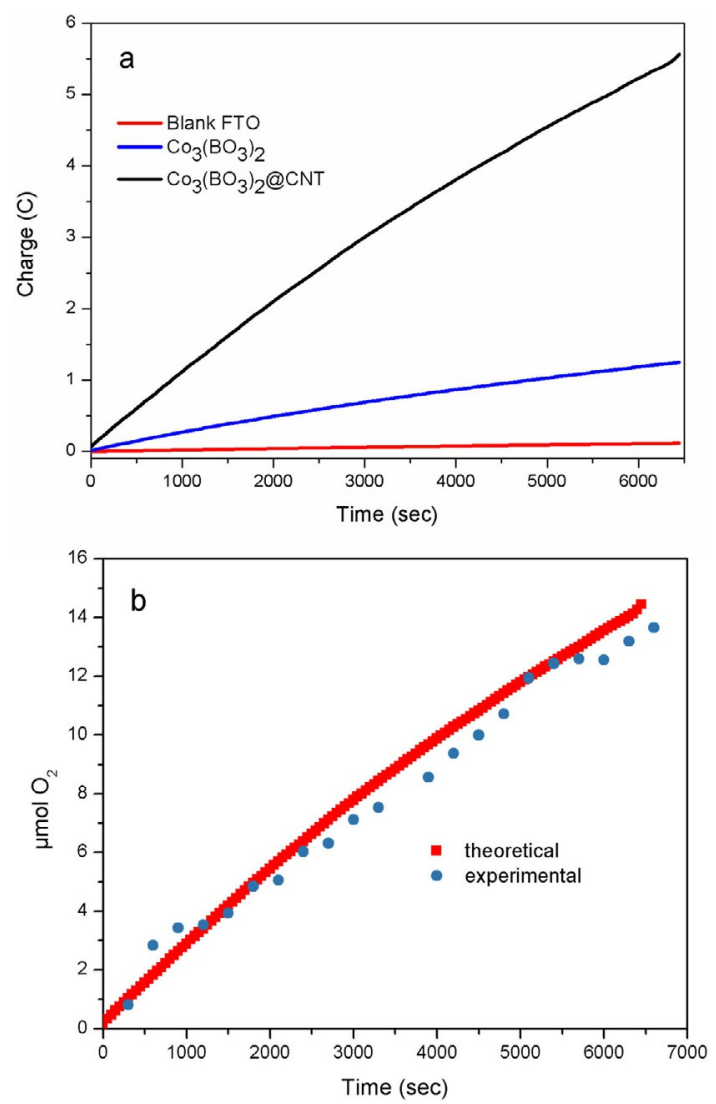

Figure 5. a) Chronocoulometric plot from controlled-potential electrolysis with $\mathrm{CO}_{3}\left(\mathrm{BO}_{3}\right)_{2} @ \mathrm{CNT}$ (top, black line), $\mathrm{CO}_{3}\left(\mathrm{BO}_{3}\right)_{2}$ (middle, blue line), blank (bottom, red) at an applied potential of $1.4 \mathrm{~V}$ vs. NHE in neutral solution. A charge vs. time trace for the background blank FTO electrode is also shown (red line). b) $\mathrm{O}_{2}$ amounts monitored by Oxygen probe (blue dot) and theoretical $\mathrm{O}_{2}$ calculated from chronocoulometric measurement assuming $100 \%$

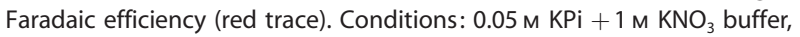
$\mathrm{pH} 7$. tion process. The similarity in binding energy profiles of the cobalt region of the pristine and post-catalytic (the electrode after $2 \mathrm{~h}$ of bulk electrolysis) electrode indicates that the catalyst is stable during the water oxidation process (Figure S4, Supporting Information).

Potentiostatic impedance studies for $\mathrm{Co}_{3}\left(\mathrm{BO}_{3}\right)_{2}$ and $\mathrm{CO}_{3}\left(\mathrm{BO}_{3}\right)_{2} @ \mathrm{CNT}$ modified electrodes were performed at pH 7.0 to evaluate their charge-transfer capacities at $1.25 \mathrm{~V}$ in a $10^{2}-$ $10^{-5} \mathrm{kHz}$ frequency range with an alternating current (AC) perturbation of $5.0 \mathrm{mV}$. Nyquist plots of the real and imaginary components of the electrochemical impedance measured at $1.25 \mathrm{~V}$ are displayed in Figure $6 \mathrm{a}$, and the equivalent electrical circuit is shown in Figure $6 \mathrm{~b}$. In this circuit, $R_{\mathrm{s}}$ is the uncompensated solution resistance between working and reference electrode obtained in the high-frequency zone. The parallel $\left(R_{\mathrm{f}} Q_{\mathrm{f}}\right)$ combination is associated with the dielectric properties and resistivity of the film, and $Q_{\mathrm{dl}} \times R_{\mathrm{ct}}$ is attributed to the Faradaic process of the OER reaction. ${ }^{[44]} R_{\mathrm{ct}}$ for $\mathrm{Co}_{3}\left(\mathrm{BO}_{3}\right)_{2} @ \mathrm{CNT}$ was found to be $550 \Omega$, which is lower than that for $\mathrm{Co}_{3}\left(\mathrm{BO}_{3}\right)_{2}$ $(1207 \Omega)$. A decrease in $R_{\mathrm{ct}}$ indicates faster charge transfer with $\mathrm{CO}_{3}\left(\mathrm{BO}_{3}\right)_{2} @ \mathrm{CNT}$. CNTs therefore play an important role in the charge-transfer characteristics of $\mathrm{Co}_{3}\left(\mathrm{BO}_{3}\right)_{2} @ \mathrm{CNT}$. Nyquist and Bode plots of $\mathrm{CO}_{3}\left(\mathrm{BO}_{3}\right)_{2} @ \mathrm{CNT}$ are compared at different potentials in Figure S5 (Supporting Information). As expected, $R_{\mathrm{ct}}$ depends strongly on the applied potential, which decreases with higher potential. The calculated values from impedance measurements are listed in Table S2 (Supporting Information). The capacitance $\left(C_{\mathrm{d} d}\right)$ from impedance measurements was calculated as $4.87 \mathrm{mF}^{\left[{ }^{[45]}\right.}$ In addition, the double layer capacitance was obtained from CV measurements performed at different scan rates in the range $0.1-0.3 \mathrm{~V}$ (Figure $\mathrm{S} 6 \mathrm{a}$, Supporting Informa-
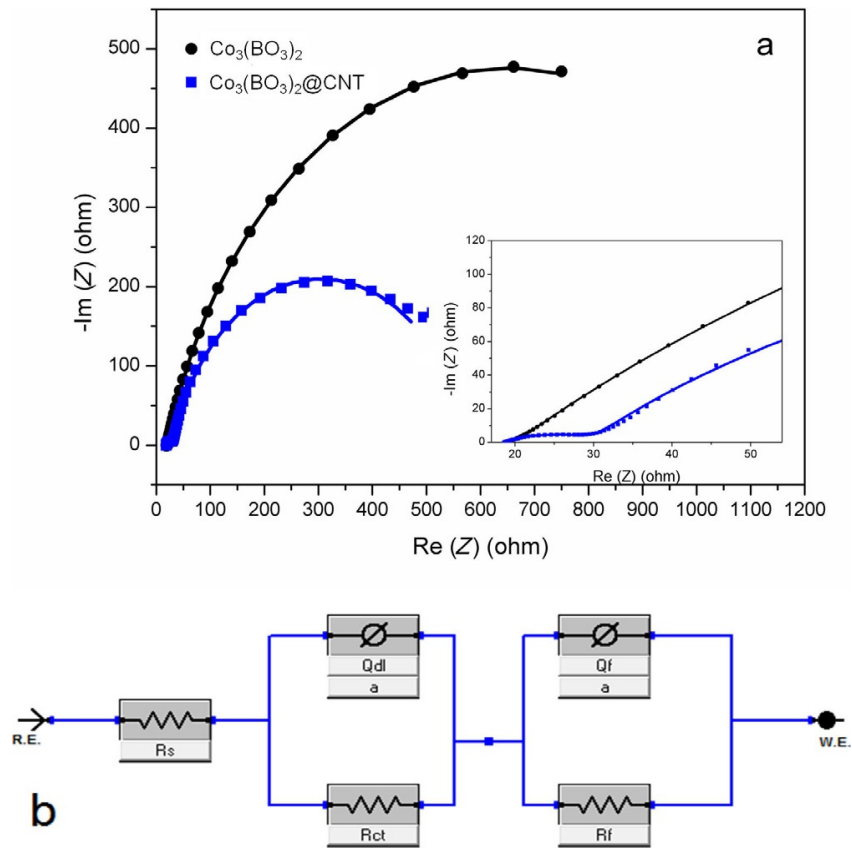

Figure 6. a) Comparison of Nyquist plot of as-prepared $\mathrm{Co}_{3}\left(\mathrm{BO}_{3}\right)_{2}$ (black dot) and $\mathrm{CO}_{3}\left(\mathrm{BO}_{3}\right)_{2} @ \mathrm{CNT}$ (blue square) recorded at a constant potential of $1.25 \mathrm{~V}$ vs. NHE with $5 \mathrm{mV}$ AC signals from $100 \mathrm{kHz}$ to $0.01 \mathrm{~Hz}$ at pH 7. Fit data is represented by line. b) Equivalent Randles model used to fit data. 
tion), in which no Faradaic current was observed. The double layer capacitance of the film can be calculated by using the relationship between current density and scan rate: the slope of the plot of current density at $0.20 \mathrm{~V}$ versus scan rate is equal to $C_{d l}$ (Figure $\mathrm{S} 6 \mathrm{~b}$ ). The $C_{\mathrm{dl}}$ value from $\mathrm{CV}$ curves is calculated as $1.7 \mathrm{mF}$, which is smaller than that calculated from EIS. The reason for this may be "pseudocapacitance", which contributes to $C_{d l}$ because of the participation of electrochemical surface reactions. ${ }^{[46]}$

$\mathrm{CV}$ measurements under various $\mathrm{pH}$ conditions $(\mathrm{pH} 3-12)$ were performed to investigate the stability and the OER kinetics of the electrodes (Figure S7, Supporting Information). According to Figure $\mathrm{S7}$, the onset potential for the $\mathrm{CO}_{3}\left(\mathrm{BO}_{3}\right)_{2}$ catalyst shifted to more negative potentials with increasing $\mathrm{pH}$. CV measurements were performed for 20 repetitive cycles at these $\mathrm{pH}$ conditions to evaluate the stability of the catalyst. The catalytic current remains constant for $\mathrm{CO}_{3}\left(\mathrm{BO}_{3}\right)_{2}$ at nearneutral conditions ( $\mathrm{pH} 6-7.5)$, whereas a significant decrease in catalytic current is observed at $\mathrm{pH}$ values above 7.5 (Figure $58 a-h$, Supporting Information). The change in catalytic current is attributed to the mechanical loss of the catalyst from the catalyst surface rather than the degradation of the catalysts. The comparison of XRD patterns for the original sample and the samples obtained after the powder forms were placed in aqueous solution at different $\mathrm{pH}$ values for $24 \mathrm{~h}$ reveal that $\mathrm{CO}_{3}\left(\mathrm{BO}_{3}\right)_{2}$ can retain its structural integrity in the $\mathrm{pH}$ range from 3 to 14 (Figure S9, Supporting Information).

The change in the potential required for a current density of $1 \mathrm{mAcm}^{-2}$ with respect to the change in $\mathrm{pH}$ was monitored to investigate the dependence of the reaction rate on proton activity. ${ }^{[23,43]}$ The linear fit of applied potential for a constant current density of $1 \mathrm{mAcm}^{-2}$ between $\mathrm{pH} 6$ and $\mathrm{pH} 7.5$ gives a slope of $-70 \mathrm{mV}$ per pH unit (Figure 7a). Tafel plots in this $\mathrm{pH}$ range were also obtained by performing a series of chronoamperometric experiments. The Tafel slope was found to decrease gradually from 88 to $75 \mathrm{mV} \mathrm{dec}^{-1}$ with increasing $\mathrm{pH}$ in the aforementioned range (Figure S10, Supporting Information, and Figure $7 \mathrm{~b}) .^{[43,47]}$ The Tafel slopes are slightly higher than 2.3RTF ${ }^{-1}$, which could be attributed to internal barriers of the electrode such as electron and mass transport. ${ }^{[48]}$ Furthermore, the Tafel slopes obtained in the range $60-80 \mathrm{mV} \mathrm{dec}^{-1}$ indicate the presence of a one-electron transfer prior to the rate-determining step during the oxygen evolution process. ${ }^{[49]}$ According to Equation (1), the dependence of proton activity on current density can be derived.

$\left(\frac{\partial E}{\partial \mathrm{pH}^{-}}\right)_{j}=-\left(\frac{\partial E}{\partial \log j}\right)_{\mathrm{pH}}\left(\frac{\partial \log j}{\partial \mathrm{pH}}\right)_{E}$

Substituting $(\partial E / \partial \mathrm{pH})_{j}=-70 \mathrm{mV} / \mathrm{pH}$ (from Figure $7 \mathrm{a}$ ) and $(\partial E / \partial \log j)_{\mathrm{pH}}=83 \mathrm{mV} \mathrm{dec}^{-1}$ (the average of the Tafel slope from Figure $7 \mathrm{~b}$ ) into Equation (1) yields $(\partial \log j / \partial \mathrm{pH})_{E}=0.84$. This result establishes an inverse first-order dependence of the current density on the concentration of $\mathrm{H}^{+}{ }^{[23,43]}$ The result implies that a proton is produced in the rate-determining step.

The electrocatalytic stability of $\mathrm{CO}_{3}\left(\mathrm{BO}_{3}\right)_{2} @ \mathrm{CNT}$ with respect to $\mathrm{pH}$ was also studied in $\mathrm{KPi}$ buffer solution in the $\mathrm{pH}$ range
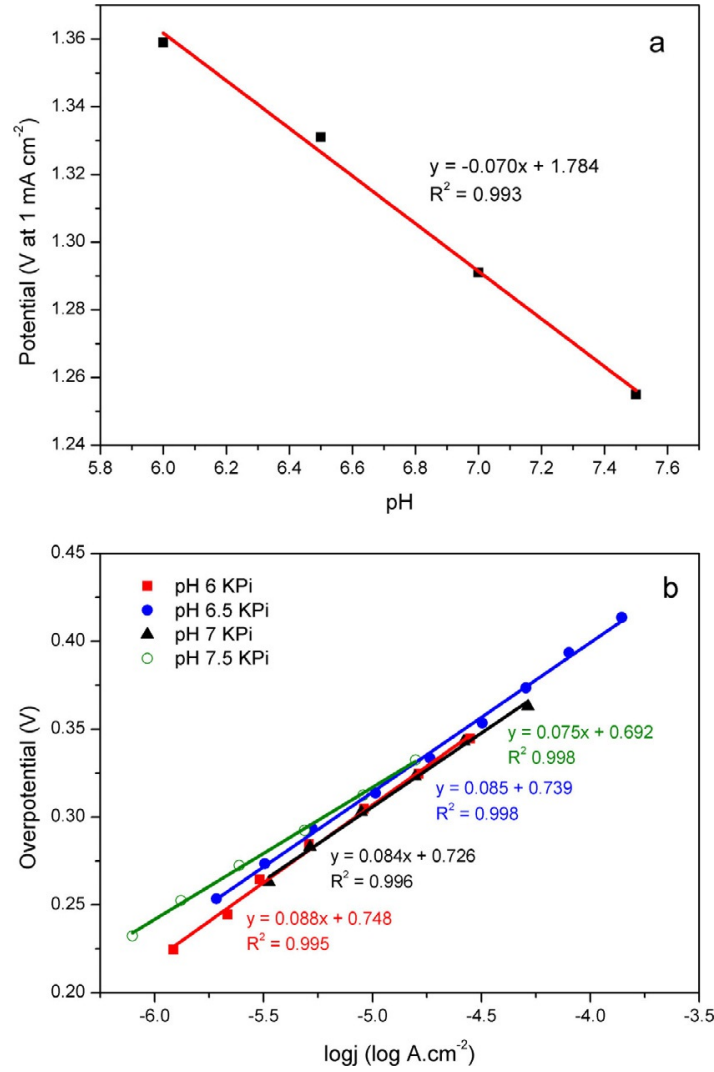

Figure 7. OER catalytic performances of $\mathrm{CO}_{3}\left(\mathrm{BO}_{3}\right)_{2}$ in solutions of various $\mathrm{pH}$. a) $\mathrm{pH}$-dependent potential change at a constant current density of $1 \mathrm{mAcm}^{-2}$, b) Tafel slopes of $\mathrm{Co}_{3}\left(\mathrm{BO}_{3}\right)_{2}$ from $\mathrm{pH} 6$ to $\mathrm{pH} 7.5$.

1-12 (Figure S11 a-h, Supporting Information). The catalytic current density remained almost stable during 100 cycles of CV scans in the $\mathrm{pH}$ range 3-11. Furthermore, the $\mathrm{Co}_{3}\left(\mathrm{BO}_{3}\right)_{2} @ \mathrm{CNT}$ catalyst retained $60 \%, 83 \%$, and $66 \%$ of its current density even at $\mathrm{pH} 1,2$, and 12, respectively. Although binding of the catalyst to the FTO substrate was improved upon incorporation of CNTs to the structure, the catalyst was stripped over the electrode under extremely acidic and basic conditions. Therefore, repetitive CV measurements indicate that ex situ preparation of the catalyst, which provides better control and a clear understanding of the structure of the catalyst, can be employed at the expense of poor attachment of the catalyst to the substrate. We have faced the effects of this drawback particularly during the $\mathrm{pH}$-dependent studies (in basic and acidic conditions, slight changes were observed with consequent CV measurements) and chronopotentiometry experiments at high current densities.

To gain insight into the catalytic performance of the cobalt borate catalyst of interest, we performed electronic structure calculations utilizing the multi-configurational Complete Active Space Self Consistent Field (CASSCF) method. ${ }^{[00,51]}$ Despite previous reports on modeling the mechanism of water oxidation for similar systems, ${ }^{[52-54]}$ there had been no attempts to utilize multi-configurational methods for any related Co system used as a water oxidation catalyst (WOC). 
Considering the existing mechanistic data in the literature ${ }^{[53,55,56]}$ and the studies pursued in our research group ${ }^{[38,40,56]}$ a series of PCET steps to oxidize water can be envisioned as shown in Figure 8. The substrate-bound aqua center with $\mathrm{a}+2$ formal charge affords the hybrid $\mathrm{Co}^{\mathrm{IV}}$ - oxo/

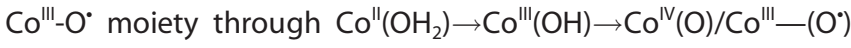
events. As the $\mathrm{O}-\mathrm{O}$ bond formation is critical for the oxidation of water, the attack of water to the $\mathrm{Co}^{\mathrm{IV}}(\mathrm{O}) / \mathrm{Co}^{\text {III- }}-\left(\mathrm{O}^{\circ}\right)$ center is our major focus.<smiles></smiles>

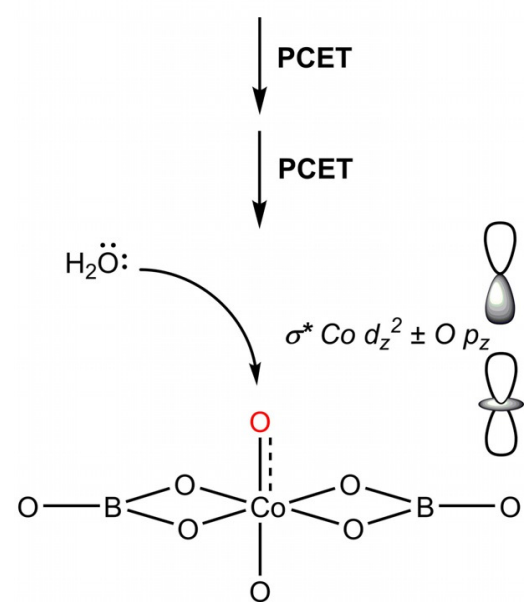

Figure 8. $\mathrm{O}-\mathrm{O}$ bond formation at the $\mathrm{Co}-\mathrm{O}$ center.

By virtue of the electronic structure method used, there are no restrictions on the distribution of electrons. This is achieved at two levels: 1) through the self-consistently converged delocalized molecular orbital picture, and 2) the ability of the CASSCF technique to utilize more than one configuration in the formulation of the wavefunction. Therefore, the electronic structure of the Co-O center is studied in an unbiased fashion. The truncated cluster model utilized herein (denoted $\mathbf{L}$ ) to represent the cobalt borate system, however, is subject to improvement, and this issue of model versus method accuracy ${ }^{[57]}$ will be addressed in a subsequent report. Although the truncated model might not capture all structural features, the local electronic structure of the active Co site is well reproduced. Moreover, our model is a good compromise between accuracy and cost, in particular for the computationally demanding electron-correlated ab initio methods. In addition, the theoretical results are supported with the experimental data from the current and earlier work done by our group, and are shown to shed light on the electronic structure of the active Co site and the mechanism of water oxidation.

The energy of the LUMO on the active Co oxo/oxyl site has recently been identified as a useful quantum descriptor for understanding the molecular basis of $\mathrm{O}-\mathrm{O}$ bond formation. ${ }^{[56]}$ As schematized in Figure 8, the LUMO is the acceptor orbital targeted by the lone pair of water. Following simple MO interaction arguments, it is expected to bear an antibonding character of $\operatorname{Cod}_{z^{2}}$ and oxygen $p_{z}$ orbitals. Our quantum mechanical calculations thus had two major goals: 1) analyzing the details of the electronic structure based on orbital interactions for the borate system, and 2) investigating the effect of the boron atom on the electronic properties of catalytic cobalt sites in cobalt borate systems to guide future studies in this direction. For the above purposes, the model outlined in Figure 8 was modified, and an all-oxygen coordinating environment was generated as well (denoted $\mathrm{L}^{\prime}$ ). Previously the second model was tested computationally. ${ }^{[52]}$

Our calculations show that the ground states of both $\mathbf{L}$ and $\mathrm{L}^{\prime}$ systems were overall quartet spin states, and the low spin (LS) doublet and high spin (HS) sextet were well separated (Table S3, Supporting Information). Therefore, the reactivity is attributed to the intermediate spin state. The HS states experiencing a greater amount of exchange are lying lower than the LS states, but they also suffer from increased repulsion of $\alpha$ electrons. The most important structural difference between $\mathbf{L}$ and $\mathrm{L}^{\prime}$ is the more elongated $\mathrm{Co}-\mathrm{O}$ bond in the borate species as depicted in Figure 9 (1.638 vs. $1.625 \AA$ ). This is a first hint about the ease of $\mathrm{O}-\mathrm{O}$ bond formation as the oxo/oxyl fragment in the former is more loosely bound to the metal.

The natural orbitals given in Figure 9 give a detailed description of the electronic structure. Electronically, both environments are local quartets. The three unpaired electrons are hosted along the Co-O site for both, which is in line with our earlier findings for similar systems.

Frontier orbitals and occupancies verify the local quartet spin arrangement of the Co oxo/oxyl center. Because of symmetry, $\operatorname{Co} d_{x y}$ being the least perturbed orbital is doubly occupied in both systems, and is followed by the two orbitals (50, 51 for $L$ and 38,39 for $L^{\prime}$ ) with a $\pi$-bonding interaction along the $\mathrm{Co}-\mathrm{O}$ bond. The highest-lying doubly occupied orbital is described by the $\operatorname{Cod}_{z^{2}}$ and $O p_{z}$ bonding interaction. Next come the singly occupied molecular orbitals (SOMOs) for both systems, in which orbital 53 is the antibonding counterpart of orbital 50 for $\mathrm{L}$, and the analogous interaction is also present between orbitals 51 and 54 for L. The same picture again holds for the $\mathbf{L}^{\prime}$ system, and the correlated orbitals are the 4138 and 42-39 pairs. The highest-lying SOMO for both is of $d_{x^{2}-y^{2}}$ symmetry. The spatial distribution of the three SOMOs shows a large degree of radical character along the Co-O bond. If a decomposition of the hybrid Cod-Op orbitals making up the SOMOs are considered, two of the total three odd electrons can be envisioned as one hosted by Co and one by $O$. Adding the third unpaired electron occupying the $d_{x^{2}-y^{2}}$ orbital, the local quartet state is built by one electron from the oxo/oxyl oxygen and two from the Co center.

Therefore, calculations show that the three unpaired electrons of the IS quartet state lie along the $\mathrm{Co}-\mathrm{O}$ bond and on Co. The electrons in the bonding and antibonding set of orbitals 50, 53 and 51, 54 contribute to a large radical character on oxygen, that is, approximately one electron. Hence, formal assignments of $\mathrm{Co}^{\mathrm{IV}}(\mathrm{O})$ or $\mathrm{Co}^{\mathrm{III}}-\left(\mathrm{O}^{\circ}\right)$ for the Co center are incom- 


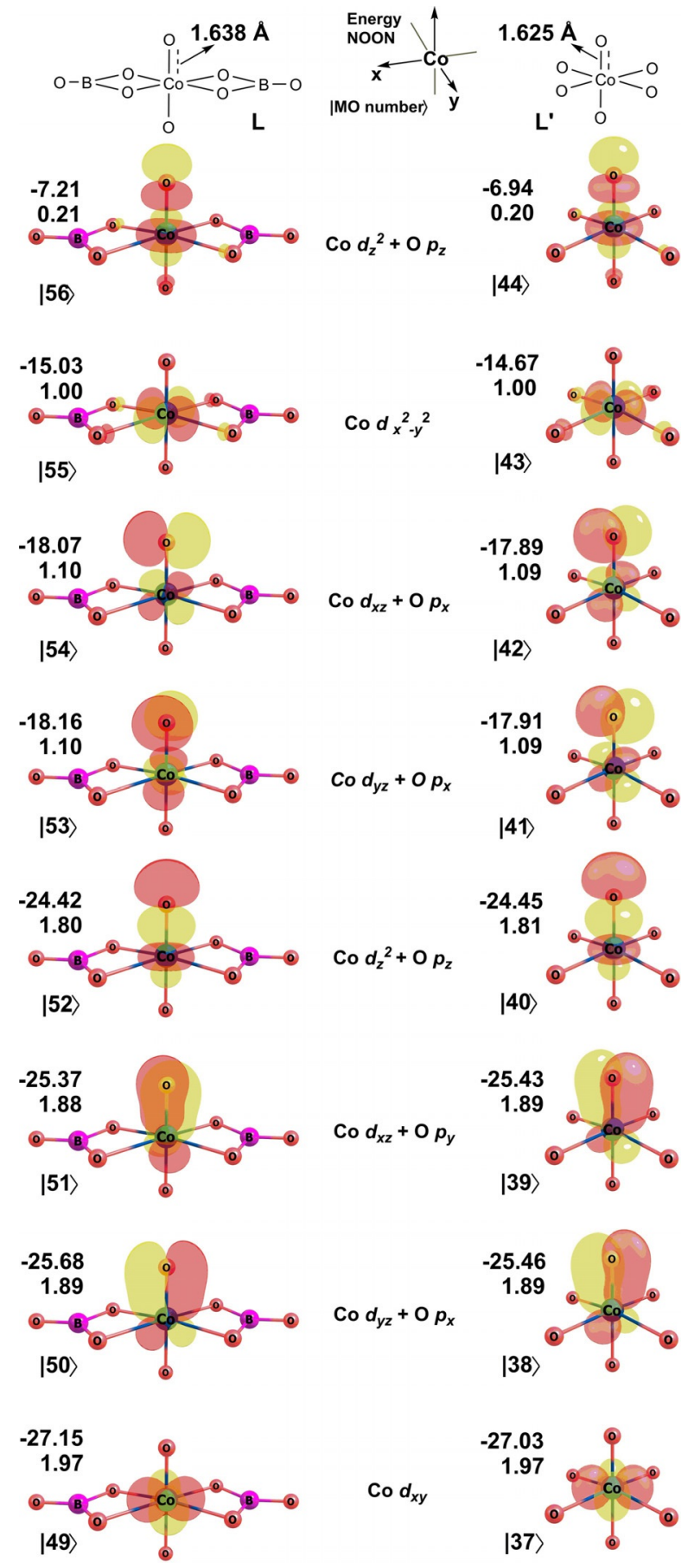

Figure 9. Active Space Orbital Plots, Occupancy Numbers (NOON) and Energies (eV) for ${ }^{4} \mathbf{L}^{\prime}$ and ${ }^{4} \mathbf{L}$ at CAS $(11,11) / c c-p V T Z$ level of theory. Surfaces were generated at 0.05 a.u.

plete descriptions, and the completely delocalized (canonical) orbital picture suggests a hybrid $\mathrm{Co}^{\mathrm{IV}}(\mathrm{O}) / \mathrm{Co}^{\mathrm{II}}-\left(\mathrm{O}^{*}\right)$ configuration. Further support for the hybrid nature of the quartet state comes from the $\mathrm{Co}-\mathrm{O}$ bond order. For the Co borate system, the bonding orbitals along the $\mathrm{Co}-\mathrm{O}$ bond are 50,51, 52 hosting a total of 5.57 electrons. The antibonding orbitals 53,54 , 56 host a total of 2.41 electrons. Overall, these give a bond order of $(5.57-2.41) / 2=1.58$, suggesting a significant double bond character, yet still far from a formal $\mathrm{Co}=\mathrm{Oxo}$ nature. Recently, a similar electronic structure fingerprint and its relation to reactivity for Co-oxo/oxyl systems was demonstrated. ${ }^{[58]}$ Moreover the bond order of around 1.6 indicates that the oxowall ${ }^{[58]}$ was indeed not broken, but there is a substantial radical character on the oxygen. Hence, it can be surmised that high valent and reactive Co moieties share this mixed Co-oxo/oxyl feature, and we are in the process of generalizing this theoretically to a number of catalytically active Co-oxo/oxyl systems.

Since the nature of the cobalt oxygen bond is of great interest for the understanding of the water oxidation mechanism, we emphasize that our experiments cannot conclusively describe the exact nature of the ligand as being an oxo or oxyl species. Our quantum chemical calculations, and particularly, the aforementioned orbital analysis, however, suggest that speculating the existence of a $\mathrm{Co}=\mathrm{Oxo}$ fragment is incorrect and the electronic structure is of a hybrid type, and hence, is better termed as Co-oxo/oxyl.

Returning to the question of the enhanced performance of the borate system compared to an all-oxygen coordinating Co environment, the LUMO energies are instructive. As shown in Figure 9, the $\sigma^{*} \mathrm{MO}$ generated from $\mathrm{Cod}_{z^{2}}$ and $O \mathrm{p}_{z}$ contributions is obtained at lower energies $(-7.21$ vs. $-6.94 \mathrm{eV})$ for the borate environment (Figure S12, Supporting Information). Thus, the LUMO for $\mathbf{L}$ has a greater electron affinity and the attack of water becomes more facile.

It should be noted that the removal of a borate ion from the crystal structure (Figure 1) also yields the formation of Co atoms with two vacancies, that is, bis-aqua complexes. As the nature of the active species is challenged, Co atoms with two vacancies on the surface should then be considered as well. The response of the character and energy of the LUMO to chemical perturbations, that is, whether there is any difference if the Co site is coordinated to more than one water substrate upon removal of a borate ligand, is also studied to address this issue. It is observed that the LUMO is always the $\operatorname{Cod} d_{z^{2}}+O p_{z^{-}}$ based molecular orbital (Figure S13, Supporting Information). Thus, independent of the number of borate-based vacancies (one or two) formed around the Co site, the reactivity is attributed to the effectively unchanged electronic structure of the Co-oxo/oxyl fragment. Moreover, the electrophilicity of the LUMO increases upon replacing the water environment with borate ligands. Thus, the attack of water to the Co-oxo/oxyl fragment in order to generate the $\mathrm{O}-\mathrm{O}$ bond is more facile for the singly vacant Co site. The Co center with three borate ligands is also considered (Figure S14, Supporting Information), and it is still the same $\operatorname{Cod}_{z^{2}}+O p_{z}$-based molecular orbital that is the LUMO. Nucleophilic attack of the substrate water to the oxygen atom of the Co-oxo/oxyl fragment is thus the key step in WO.

\section{Conclusions}

A cobalt-borate-based catalyst with a well-defined crystal structure was prepared, followed by the preparation of its hybrid compound with CNTs. There are several advantages of this methodology: 1) The structure of the catalytic site is clear, 
which forms the basis of computational studies. 2) The stability of the catalyst was confirmed by characterization studies. 3) The effect of a carbon-based support on the morphology and electrocatalytic performance was studied.

The Co-Borate system was employed as a water oxidation electrocatalyst to gain insight into the origin of its enhanced catalytic activity. Inspection of the crystal structure of $\mathrm{CO}_{3}\left(\mathrm{BO}_{3}\right)_{2}$ revealed that each cobalt site is in an octahedral environment, created by oxygen atoms of the trigonal planar borate groups. The incorporation of CNTs resulted in a decrease in the Tafel slope and faster charge transfer, which is attributed to the conductive behavior of CNTs. A significantly lower onset overpotential $(206 \mathrm{mV})$ and overpotential for $10 \mathrm{mAcm}^{-2}(487 \mathrm{mV})$ was recorded for $\mathrm{Co}_{3}\left(\mathrm{BO}_{3}\right)_{2} @ \mathrm{CNT}$, which is attributed mainly to the increase in surface concentration. The catalyst was proven to be stable in the $\mathrm{pH}$ range $3-14$, which showed that it is relatively more stable in acidic conditions compared with cobalt oxides. Tafel slopes obtained in the $\mathrm{pH}$ range $6.0-7.5$ implied that the rate-determining step involves the release of a proton (presumably at the Co-oxo/oxyl- $\mathrm{OH}_{2}$ bond formation step). Overall, our studies indicate that the effect of the carbonbased support is twofold: 1) It enhances the surface area, and thus, the surface concentration of the electrode. 2) The support also improves the electronic conductivity of the assembly, which, in turn, enhances the catalytic activity of each cobalt site.

Computational studies performed on a single cobalt site indicate that the $\mathrm{O}-\mathrm{O}$ bond-forming species has a mixed $\mathrm{Co}$ oxo/oxyl character, and nucleophilic attack of water to the cobalt-oxo intermediate should be critical. Furthermore, the electronic properties of two cobalt sites, one of which is surrounded by borate groups and the latter by oxide groups, were interrogated to compare catalytically active sites in borate and oxide systems. It was found that the Co-O bond is weaker and the LUMO is more electrophilic in the cobaltborate intermediate, which makes it a more reactive species toward the nucleophilic attack of water. Electrophilicity of the Co-oxo/oxyl center can be probed by molecular orbital analysis, which might be a useful tool for the realization of new Co species as potent WOCs. Detailed electronic structure calculations employing multi-reference techniques on various $\mathrm{Co}-\mathrm{O}$ systems are underway to corroborate the nature of the Cooxo/oxyl bonding and reactivity.

The interest in cobalt borate water oxidation electrocatalysts has recently been revived as novel synthetic methods have been introduced for the preparation of cobalt borate hybrid systems. The experimental and computational studies outlined in this study suggest that the incorporation of borate groups in cobalt-based catalysts is a viable method for the development of efficient and robust water oxidation electrocatalysts. More studies are on the way in order to utilize their robustness even under neutral and slightly acidic conditions, as well as their enhanced activities.

\section{Experimental Section}

\section{Chemicals and solutions}

Cobalt nitrate $\mathrm{Co}\left(\mathrm{NO}_{3}\right)_{2} \cdot 6 \mathrm{H}_{2} \mathrm{O}$ (Sigma-Aldrich, >97.0\%), $\mathrm{H}_{3} \mathrm{BO}_{3}$ (Sigma-Aldrich, 98.0\%) and solvents were used as received. All the solutions were prepared with Millipore Milli-Q deionized water with a resistivity of $18.2 \mathrm{~m} \Omega \mathrm{cm}^{-1}$.

\section{Synthesis of $\mathrm{CO}_{3}\left(\mathrm{BO}_{3}\right)_{2}$}

A solid-state heating treatment that is slightly different from those reported previously was applied. ${ }^{[59]} \mathrm{Co}\left(\mathrm{NO}_{3}\right)_{2} \cdot 6 \mathrm{H}_{2} \mathrm{O}$ (0.03 mole, $8.76 \mathrm{~g})$ and $\mathrm{H}_{3} \mathrm{BO}_{3}(0.02$ mole, $1.241 \mathrm{~g})$ were mixed and ground homogeneously. The mixture was then heat-treated in an alumina crucible at $450^{\circ} \mathrm{C}$ for $6 \mathrm{~h}$. The sample was cooled, ground again, and then treated at $900^{\circ} \mathrm{C}$ for $48 \mathrm{~h}$. The product, upon cooling down to room temperature, was washed with copious amounts of water and acetone, and dried in a vacuum desiccator.

\section{Preparation of $\mathrm{CO}_{3}\left(\mathrm{BO}_{3}\right)_{2}$-modified electrodes}

FTO electrodes $\left(1 \times 2 \mathrm{~cm}, 2 \mathrm{~mm}\right.$ slides with $\approx 7 \Omega \mathrm{sq}^{-1}$ surface resistivity and $\approx 80 \%$ transmittance) were washed by sonication for $10 \mathrm{~min}$ in basic soapy solution, deionized water, and isopropanol, followed by an annealing process at $400{ }^{\circ} \mathrm{C}$ for $30 \mathrm{~min}$. The catalyst was coated onto an FTO electrode through a drop-casting method. A mixture of catalyst $(5 \mathrm{mg})$, water $(500 \mu \mathrm{L}), \mathrm{DMF}(500 \mu \mathrm{L})$, and Nafion (100 $\mu \mathrm{L})$ was sonicated for 30 min to make a stable suspension. Then, the sonicated suspension of the catalyst $(50 \mu \mathrm{L})$ was dropped onto a clean FTO electrode $\left(1 \mathrm{~cm}^{2}\right)$. The electrode was then dried in an oven at $80^{\circ} \mathrm{C}$ for $10 \mathrm{~min}$. This process was repeated three times and the modified electrode was left under desiccation until further use for CV and bulk electrolysis studies. The electrode was rinsed with deionized water prior to use.

\section{Treatment of multiwalled carbon nanotubes (CNTs)}

CNTs were treated with acid mixture prior to use according to a method reported previously to remove impurities including amorphous carbon and metal catalyst impurities. ${ }^{[60]}$ Briefly, CNTs $(50 \mathrm{mg}$ ) were treated in $1: 3$ concentrated $\mathrm{HNO}_{3}$ and $\mathrm{H}_{2} \mathrm{SO}_{4}$ solution $(25 \mathrm{~mL}$ ) under sonication for $2 \mathrm{~h}$. The suspension was then left at room temperature overnight. After the acid treatment, the CNTs were separated by using ultracentrifugation repeatedly, and washed with double distilled water until the solution reached neutral $\mathrm{pH}$. Finally, the CNTs were dried at $60^{\circ} \mathrm{C}$ under vacuum. The CNTs obtained were then used for the preparation of $\mathrm{CO}_{3}\left(\mathrm{BO}_{3}\right)_{2} @ \mathrm{CNT}$.

\section{Preparation of $\mathrm{Co}_{3}\left(\mathrm{BO}_{3}\right)_{2} @ \mathrm{CNT}$ hybrid catalyst}

$\mathrm{CO}_{3}\left(\mathrm{BO}_{3}\right)_{2}(5 \mathrm{mg})$ and pretreated CNTs $(0.5 \mathrm{mg})$ were separately ultrasonicated in DMF/water $(1: 1 \mathrm{v} / \mathrm{v})$ mixture $(500 \mu \mathrm{L})$ for $2 \mathrm{~h}$ to obtain a suspension. The two suspensions were then mixed. Nafion $(100 \mu \mathrm{L})$ was added to the mixture and ultrasonicated for $2 \mathrm{~h}$. The sonicated suspension of the catalyst $(50 \mu \mathrm{L})$ was then dropped onto a clean FTO electrode $\left(1 \mathrm{~cm}^{2}\right)$. The electrode was then dried in an oven at $80^{\circ} \mathrm{C}$ for $10 \mathrm{~min}$. This process was repeated three times and the modified electrode was left under desiccation.

\section{Electrochemical studies}

Electrochemical studies were performed at room temperature using a Gamry Instrument Interface 1000 Potentiostat/Galvanostat. 
A conventional three-electrode electrochemical cell was used with a $\mathrm{Ag} / \mathrm{AgCl}$ electrode $(3.5 \mathrm{M} \mathrm{KCl})$ as the reference electrode, Pt wire as a counter electrode, and fluorine-doped tin oxide (FTO) as the working electrode. All potentials were measured versus the Ag/ $\mathrm{AgCl}$ reference electrode and were reported versus the normal hydrogen electrode (NHE) using the equation $E(\mathrm{NHE})=E(\mathrm{Ag} / \mathrm{AgCl})+$ $0.205 \mathrm{~V}$. Buffer solutions were prepared using $\mathrm{K}_{2} \mathrm{HPO}_{4}$ and $\mathrm{KH}_{2} \mathrm{PO}_{4}$ $(\mathrm{KPi})$, and then adjusted by adding $\mathrm{H}_{3} \mathrm{PO}_{4}$ or $\mathrm{KOH}$ to achieve the desired $\mathrm{pH}$. Cyclic voltammograms (CVs) were recorded at a scan rate of $50 \mathrm{mV} \mathrm{s}^{-1}$ in $50 \mathrm{mM} \mathrm{KPi} \mathrm{(pH} \mathrm{7)} \mathrm{containing} 1 \mathrm{M} \mathrm{KNO}_{3}$ as electrolyte between 0.2 and $1.7 \mathrm{~V}$ (vs. NHE). For double-layer capacitance determinations, the scan rate was varied between 20 and $200 \mathrm{mV} \mathrm{s}^{-1}$ in the potential range $0.1-0.3 \mathrm{~V}$, at which no Faradaic current was observed. The electrochemical double layer capacitance $\left(C_{\mathrm{dl}}\right)$ was extracted from $\mathrm{j}_{\mathrm{c}}=v \times C_{\mathrm{dl}}$, in which $v$ is the scan rate and $j_{c}$ the current density for the specific curve at $0.2 \mathrm{~V}$. Chronopotentiometric (CP) measurements were recorded at a constant current density for $1 \mathrm{mAcm}^{-2}$ and $10 \mathrm{mAcm}^{-2}$ in a neutral solution under vigorous stirring. All experiments were performed under a nitrogen atmosphere.

\section{Bulk water electrolysis and Tafel analysis}

Bulk water electrolysis studies were performed with a two-compartment cell with a glass frit separation. A Pt wire counter electrode was placed in one compartment, and the FTO working electrode and $\mathrm{Ag} / \mathrm{AgCl}$ reference electrode were placed in the other compartment. The electrolysis experiments were performed in $\mathrm{KPi}$ buffer ( $\mathrm{pH}$ 7.0) solution containing $1 \mathrm{M} \mathrm{KNO}_{3}$ as supporting electrolyte. Tafel data were collected under the same conditions at different applied potentials using the steady current density of an equilibrium time of $600 \mathrm{~s}$. Oxygen evolution was determined with a YSI5100 oxygen-sensing instrument equipped with a dissolved oxygen field probe inserted into the anodic compartment.

\section{Electrochemical impedance spectroscopy (EIS)}

EIS measurements were performed with a Gamry Instruments Interface 1000 Potentiostat/ Galvanostat and evaluated with the Gamry EIS 300/Physical electrochemistry software at $\mathrm{pH} 7$ for the $\mathrm{Co}_{3}\left(\mathrm{BO}_{3}\right)_{2}$ and $\mathrm{CO}_{3}\left(\mathrm{BO}_{3}\right)_{2} @ \mathrm{CNT}$ electrodes at $1.25 \mathrm{~V}$ with initial conditioning for $5 \mathrm{~min}$. The measurements were taken in the frequency range $0.01-100 \mathrm{kHz}$ with an alternating current (AC) perturbation of $5.0 \mathrm{mV}$.

\section{Computational details}

Structures were optimized with the $\mathrm{UMO6L}^{[61]}$ functional and Def2TZVP ${ }^{[62,63]}$ basis set as implemented in Gaussian 09 software. ${ }^{[63]}$ $\mathrm{CASCSF}^{[50]}$ calculations were performed on optimized UM06L geo-

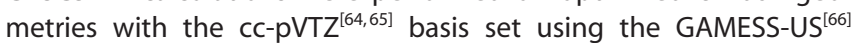
package. An active space of 11 electrons in 11 orbitals [CAS $(11,11)$ ] was constructed to include the $\mathrm{d}$ orbitals of $\mathrm{Co}$ and $\mathrm{p}$ orbitals of $\mathrm{O}$ as well as unfilled $d$ orbitals on Co. To examine the uniformity of the CAS, natural orbitals (NOs) were analyzed carefully for all the species discussed. NOs diagonalize the one-electron density matrix having nonintegral diagonal elements from 0 to 2 defined as the occupation numbers (NOON). NOs are a convenient way of building the MCSCF wavefunction as they provide the shortest configuration expansion possible. NOONs and orbital isosurface plots were used to eliminate solutions with undesired orbital rotations. The SCF procedure resulted in a slight mixing of the MCSCF optimized orbitals, but careful inspection of the NOs revealed that the Co3d set and $\mathrm{O} 2 \mathrm{p}$ set were always in the AS. Conservation of the active orbitals for each case was also carefully checked.

\section{Acknowledgements}

The authors thank the Science and Technology Council of Turkey, TUBITAK (Project No: 214Z095) for financial support. E.U. thanks TUBITAK for support (Project No: 1929B011500059). Y.D. thanks BAGEP and TÜBA-GEBIP for young investigator awards and ECOSTBio (CM 1305) for support. TUBITAK TRGRID infrastructure is gratefully acknowledged for HPC resources.

\section{Conflict of interest}

The authors declare no conflict of interest.

Keywords: borate - cobalt $\cdot$ density functional calculations electrocatalysis $\cdot$ water oxidation

[1] T. Y. Ma, S. Dai, M. Jaroniec, S. Z. Qiao, Angew. Chem. Int. Ed. 2014, 53, 7281 -7285; Angew. Chem. 2014, 126, 7409-7413.

[2] Q. Yin, J. M. Tan, C. Besson, Y. V. Geletii, D. G. Musaev, A. E. Kuznetsov, Z. Luo, K. I. Hardcastle, C. L. Hill, Science 2010, 328, 342-345.

[3] Y. Lee, J. Suntivich, K. J. May, E. E. Perry, Y. Shao-Horn, J. Phys. Chem. Lett. 2012, 3, 399-404.

[4] M. W. Kanan, D. G. Nocera, Science 2008, 321, 1072-1075.

[5] P. Du, R. Eisenberg, Energy Environ. Sci. 2012, 5, 6012-6021.

[6] D. G. Nocera, Acc. Chem. Res. 2012, 45, 767-776.

[7] A. Singh, L. Spiccia, Coord. Chem. Rev. 2013, 257, 2607-2622.

[8] M. S. Faber, S. Jin, Energy Environ. Sci. 2014, 7, 3519-3542.

[9] J. R. Galán-Mascarós, ChemElectroChem 2015, 2, 37-50.

[10] X. Deng, H. Tuysuz, ACS Catal. 2014, 4, 3701-3714.

[11] I. Roger, M. A. Shipman, M. D. Symes, Nat. Rev. Chem. 2017, 1, 0003.

[12] S. Chen, S. Z. Qiao, ACS Nano 2013, 7, 10190-10196.

[13] X. Liu, Z. Chang, L. Luo, T. Xu, X. Lei, J. Liu, X. Sun, Chem. Mater. 2014, 26, $1889-1895$.

[14] H. Y. Wang, S. F. Hung, H. Y. Chen, T. S. Chan, H. M. Chen, B. Liu, J. Am. Chem. Soc. 2016, 138, 36-39.

[15] T. Grewe, X. Deng, C. Weidenthaler, F. Schüth, H. Tüysüz, Chem. Mater. 2013, 25, 4926-4935.

[16] C.-C. Lin, C. C. L. McCrory, ACS Catal. 2017, 7, 443-451.

[17] J. Masa, P. Weide, D. Peeters, I. Sinev, W. Xia, Z. Sun, C. Somsen, M. Muhler, W. Schuhmann, Adv. Energy Mater. 2016, 6, 1502313.

[18] P. Chen, K. Xu, Y. Tong, X. Li, S. Tao, Z. Fang, W. Chu, X. Wu, C. Wu, Inorg. Chem. Front. 2016, 3, 236-242.

[19] A. Han, H. Chen, Z. Sun, J. Xu, P. Du, Chem. Commun. 2015, 51, $11626-$ 11629.

[20] G. Zhang, G. Wang, Y. Liu, H. Liu, J. Qu, J. Li, J. Am. Chem. Soc. 2016, $138,14686-14693$.

[21] S. Pintado, S. Goberna-Ferron, E. C. Escudero-Adan, J. R. Galan-Mascaros, J. Am. Chem. Soc. 2013, 135, 13270-13273.

[22] Y. Yamada, K. Oyama, R. Gates, S. Fukuzumi, Angew. Chem. Int. Ed. 2015, 54, 5613-5617; Angew. Chem. 2015, 127, 5705-5709.

[23] H. Kim, J. Park, I. Park, K. Jin, S. E. Jerng, S. H. Kim, K. T. Nam, K. Kang, Nat. Commun. 2015, 6, 8253.

[24] D. González-Flores, I. Sánchez, I. Zaharieva, K. Klingan, J. Heidkamp, P. Chernev, P. W. Menezes, M. Driess, H. Dau, M. L. Montero, Angew. Chem Int. Ed. 2015, 54, 2472-2476; Angew. Chem. 2015, 127, 2502-2506.

[25] C. L. Farrow, D. K. Bediako, Y. Surendranath, D. G. Nocera, S. J. L. Billinge, J. Am. Chem. Soc. 2013, 135, 6403-6406.

[26] A. J. Esswein, Y. Surendranath, S. Y. Reece, D. G. Nocera, Energy Environ. Sci. 2011, 4, 499-504.

[27] Y. Surendranath, M. Dincă, D. G. Nocera, J. Am. Chem. Soc. 2009, 131, $2615-2620$. 
[28] P. Chen, K. Xu, T. Zhou, Y. Tong, J. Wu, H. Cheng, X. Lu, H. Ding, C. Wu, Y. Xie, Angew. Chem. Int. Ed. 2016, 55, 2488-2492; Angew. Chem. 2016 $128,2534-2538$.

[29] R. Ge, H. Du, K. Tao, Q. Zhang, L. Chen, ACS Appl. Mater. Interfaces 2017, 9, $15383-15387$.

[30] X. Ren, R. Ge, Y. Zhang, D. Liu, D. Wu, X. Sun, B. Du, Q. Wei, J. Mater. Chem. A 2017, 5, 7291-7294.

[31] X. Ji, S. Hao, F. Qu, J. Liu, G. Du, A. M. Asiri, L. Chen, X. Sun, Nanoscale 2017, 9, 7714-7718.

[32] L. Cui, F. Qu, J. Liu, G. Du, A. M. Asiri, X. Sun, ChemSusChem 2017, 10 $1370-1374$.

[33] G. Zhu, R. Ge, F. Qu, G. Du, A. M. Asiri, Y. Yao, X. Sun, J. Mater. Chem. A 2017, 5, 6388-6392.

[34] L. Yang, D. Liu, S. Hao, R. Kong, A. M. Asiri, C. Zhang, X. Sun, J. Mater. Chem. A 2017, 5, 7305-7308.

[35] M. Ma, F. Qu, X. Ji, D. Liu, S. Hao, G. Du, A. M. Asiri, Y. Yao, L. Chen, X. Sun, Small 2017, 13, 1700394.

[36] L. Chen, X. Ren, W. Teng, P. Shi, Chem. Eur. J. 2017, 23, 9741 - 9745.

[37] J. P. McEvoy, G. W. Brudvig, Chem. Rev. 2006, 106, 4455-4483.

[38] M. Aksoy, S. V. K. Nune, F. Karadas, Inorg. Chem. 2016, 55, 4301-4307.

[39] D. J. Wasylenko, C. Ganesamoorthy, J. Borau-Garcia, C. P. Berlinguette, Chem. Commun. 2011, 47, 4249-4251.

[40] S. V. K. Nune, A. T. Basaran, E. Ülker, R. Mishra, F. Karadas, ChemCatChem 2017, 9, 300-307.

[41] H. S. Ahn, T. D. Tilley, Adv. Funct. Mater. 2013, 23, 227-233.

[42] D. Ressnig, M. Shalom, J. Patscheider, R. Moré, F. Evangelisti, M. Antonietti, G. R. Patzke, J. Mater. Chem. A 2015, 3, 5072-5082.

[43] Y. Surendranath, M. W. Kanan, D. G. Nocera, J. Am. Chem. Soc. 2010, 132, $16501-16509$.

[44] L. Han, P. Tang, A. Reyes-Carmona, B. Rodriguez-Garcia, M. Torrens, J. R. Morante, J. Arbiol, J. R. Galan-Mascaros, J. Am. Chem. Soc. 2016, 138, $16037-16045$

[45] D. Merki, H. Vrubel, L. Rovelli, S. Fierro, X. Hu, Chem. Sci. 2012, 3, 2515 2525.

[46] B. E. Conway, V. Birss, J. Wojtowicz, J. Power Sources 1997, 66, 1-14.

[47] E. Gileadi, Electrode Kinetics for Chemists, Chemical Engineers and Materials Scientists, Wiley-VCH, New York, 1993.

[48] F. Yu, F. Li, B. Zhang, H. Li, L. Sun, ACS Catal. 2015, 5, 627-630.

[49] K. Jin, A. Chu, J. Park, D. Jeong, S. E. Jerng, U. Sim, H.-Y. Jeong, C. W. Lee, Y.-S. Park, K. D. Yang, G. K. Pradhan, D. Kim, N.-E. Sung, S. H. Kim, K. T. Nam, Sci. Rep. 2015, 5, 10279.

[50] M. W. Schmidt, M. S. Gordon, Annu. Rev. Phys. Chem. 1998, 49, 233-266.

[51] B. O. Roos in Advances in Chemical Physics: Ab Initio Methods in Quantum Chemistry, Part 2, Vol. 65 (Ed.: K. P. Lawley), Wiley, New York, 2007 pp. $399-445$
[52] M. Schilling, G. R. Patzke, J. Hutter, S. Luber, J. Phys. Chem. C 2016, 120, $7966-7975$.

[53] G. Mattioli, P. Giannozzi, A. A. Bonapasta, L. Guidoni, J. Am. Chem. Soc 2013, 135, 15353-15363.

[54] D. W. Crandell, S. Ghosh, C. P. Berlinguette, M. H. Baik, ChemSusChem 2015, 8, 844-852.

[55] D. J. Wasylenko, R. D. Palmer, C. P. Berlinguette, Chem. Commun. 2013, 49, 218-227.

[56] E. P. Alsaç, E. Ülker, S. V. K. Nune, Y. Dede, F. Karadas, Chem. Eur. J. 2018, 24, 4856-4863.

[57] E. A. Pidko, ACS Catal. 2017, 7, 4230-4234.

[58] B. Wang, Y.-M. Lee, W.-Y. Tcho, S. Tussupbayev, S.-T. Kim, Y. Kim, M. S. Seo, K.-B. Cho, Y. Dede, B. C. Keegan, T. Ogura, S. H. Kim, T. Ohta, M.-H. Baik, K. Ray, J. Shearer, W. Nam, Nat. Commun. 2017, 8, 14839.

[59] H. Güler, B. Tekin, Inorg. Mater. 2009, 45, 538-542.

[60] G. Xu, B. Li, X. Luo, Sens. Actuators B 2013, 176, 69-74.

[61] Y. Zhao, D. G. Truhlar, J. Chem. Phys. 2006, 125, 194101.

[62] F. Weigend, R. Ahlrichs, Phys. Chem. Chem. Phys. 2005, 7, 3297-3305.

[63] Gaussian 09, Revision D.01, M. J. Frisch, G. W. Trucks, H. B. Schlegel, G. E. Scuseria, M. A. Robb, J. R. Cheeseman, G. Scalmani, V. Barone, B. Mennucci, G. A. Petersson, H. Nakatsuji, M. Caricato, X. Li, H. P. Hratchian, A. F. Izmaylov, J. Bloino, G. Zheng, J. L. Sonnenberg, M. Hada, M. Ehara, K. Toyota, R. Fukuda, J. Hasegawa, M. Ishida, T. Nakajima, Y. Honda, O. Kitao, H. Nakai, T. Vreven, J. A. Montgomery, Jr., J. E. Peralta, F. Ogliaro, M. Bearpark, J. J. Heyd, E. Brothers, K. N. Kudin, V. N. Staroverov, R. Kobayashi, J. Normand, K. Raghavachari, A. Rendell, J. C. Burant, S. S. Iyengar, J. Tomasi, M. Cossi, N. Rega, J. M. Millam, M. Klene, J. E. Knox, J. B. Cross, V. Bakken, C. Adamo, J. Jaramillo, R. Gomperts, R. E. Stratmann, O. Yazyev, A. J. Austin, R. Cammi, C. Pomelli, J. W. Ochterski, R. L. Martin, K. Morokuma, V. G. Zakrzewski, G. A. Voth, P. Salvador, J. J. Dannenberg, S. Dapprich, A. D. Daniels, Ö. Farkas, J. B. Foresman, J. V. Ortiz, J. Cioslowski, D. J. Fox, Gaussian, Inc. Wallingford CT, 2009.

[64] T. H. Dunning, J. Chem. Phys. 1989, 90, 1007-1023.

[65] R. A. Kendall, T. H. Dunning, R. J. Harrison, J. Chem. Phys. 1992, 96, 6796-6806.

[66] M. W. Schmidt, K. K. Baldridge, J. A. Boatz, S. T. Elbert, M. S. Gordon, J. H. Jensen, S. Koseki, N. Matsunaga, K. A. Nguyen, S. Su, T. L. Windus, M. Dupuis, J. A. Montgomery, J. Comput. Chem. 1993, 14, 1347-1363.

Manuscript received: March 20, 2018

Revised manuscript received: April 30, 2018

Accepted manuscript online: May 18, 2018

Version of record online: July 5, 2018 